\title{
Audit of design estimates and organizational and technological documentation in the process of construction expertise
}

\author{
Dmitry Topchiy ${ }^{*}$ and Marina Katasonova \\ Moscow State University of Civil Engineering, Yaroslavskoe shosse, 26, Moscow, 129337, Russia
}

\begin{abstract}
This article examines the problem of insufficient determination of the requirements for admissions, qualifications of experts and experts in the field of expertise and audit of construction, reconstruction and reprofiling. The place and role of expertise in construction, the prerequisites and the grounds for its conduct are analyzed. The necessity to expand and specify the legislative platform on the basis of which judicial expert and technical activity is conducted has been revealed and substantiated. On the basis of the conducted research using empirical data, a minimal enough link of the executors per unit volume of the examination object is formed.
\end{abstract}

\section{Introduction}

The creation of a construction object is closely interrelated with the influence of the construction construction process on the environment and the architectural and planning structure of residential areas. While the building itself, the engineering systems in it must ensure the complete safety of its tenants and the population as a whole.

The main goal is the design and construction of buildings with reduced material consumption (ultimately cost). At the same time, the applied structures and materials during construction and their finishing should comply with all standards and requirements for strength, stability under operational loads, in the event of emergency situations of a natural nature, as well as man-made phenomena [4].

The abundance of construction products has led to the organization of public service for the supervision of the creation of buildings and structures, whose function is to comprehensively assess the quality of technical documentation for urban planning and construction, and monitor the quality of real estate in accordance with the regulatory and legislative framework of the Russian Federation [1].

Centuries of world history, including in Russia, has expertise in construction. With the increase in the construction of residential, industrial and civil buildings, structures, the development of the construction business began to appear the need to organize state supervision and control of this activity. Examination was especially in demand during the reign of Peter 1, when accidents and destruction at large sites began to have disastrous consequences. Examination today is a lever of state management of construction and

* Corresponding author: marinakat98@gmail.com 
territorial activities, which optimizes the use of natural, financial and labor resources and forms the basis for improving the quality and comfort of human life in Russia [1].

But social relations are developing not without difficulties, including conflicts that are formed during the formation of a complex system of modern construction, the erection and operation of buildings and structures, buildings. To solve these issues is impossible without the construction and technical knowledge, the effective form of which is the construction and technical expertise $[1,2]$.

\section{Materials and Methods}

The appearance of civil disputes regarding the quality and cost of construction products, the ownership of real estate in general and arbitration courts, establishing the correctness and legitimacy of the course of construction production, investigating criminal cases of accidents, accidents and destruction in construction, we come to the only right and undeniable the decision of the judicial construction and technical expertise [3].

In order to conduct forensic expertise, it is necessary to accurately fulfill the requirements of the Constitution of the Russian Federation, the laws of the Russian Federation, decrees of the President, Government decrees. The activity on forensic technical expertise is regulated by the Federal Law of May 31, 2001 No. 73 "On the state forensic expert activity in the Russian Federation".

The legislative framework also includes international agreements ratified by the country's legislative authority. The normative-methodological basis of the examination includes documents defining the status and competence of experts, the procedure and bases for organizing their work at the federal and regional levels. Violation of the law is unacceptable and entails responsibility established by the legislation of the Russian Federation.

If, as a result of the examination, serious violations of regulatory requirements were identified that could lead to destruction, reduction in the bearing capacity or stability of buildings and structures, the expert body takes measures in the form of penalties or cancellation of licenses issued to them [7].

With regard to the judicial construction and technical expertise, whatever the expert establishes (assessment of the state of the building, amount of wear, cause of the accident, etc.), from a procedural point of view, all conclusions will be facts and be relevant to a criminal or civil case.

The subject of construction and technical forensic examination is the process of establishing the facts and conducting cases in the field of construction about administrative and criminal violations in a court of general jurisdiction, as well as in an arbitration court.

The production of building structures, products and materials, the performance of construction work may or may not belong to products of the construction industry. The cost of construction sites and work performed may also not correspond to the actual, which, in turn, is an administrative violation. The fact of compliance with project and executive documentation, causes, conditions, circumstances and mechanism of an accident or accident, compliance of actions of construction participants, possible transformation of land plots, all this is also the subject of a study of judicial construction and technical expertise [6].

The structure of the optimal expert technical opinion is regulated by the procedural law (Article 26.4 of the APC RF, Code of Administrative Offenses of the Russian Federation, Article 204 of the Code of Criminal Procedure, Article 86 of the Code of Civil Procedure of the Russian Federation, Article 88 of the APC RF) and departmental instructions, special literature and theses. An expert opinion is drawn up in writing by a knowledgeable person who is criminally or administratively liable for it $[3,12,13]$. 
Before an expert issues a conclusion in an expert institution, he is obliged in accordance with part 2 of article 199 of the Code of Criminal Procedure, part 2 of article 80 of the Code of Civil Procedure of the Russian Federation, part 4 of Art. 82 of the APC RF to be informed by the head of the expert institution about his rights, duties, responsibility for giving a knowingly false conclusion and disclosing preliminary investigation data. The expert, here, must sign and date of receipt of the clarifications [3].

This document contains an introduction, research and conclusions.

In the introductory part, the installation data are specified, which determine their direction and individualize the conducted research, the subject matter of the examination, the date and number of the signing of the opinion, as well as the date of receipt of the materials for the examination.

The research part, in turn, consists of $[8,9,10,11,14,15]$ :

- Visual and instrumental examination;

- Laboratory research;

- Analysis of project, working and performing documentation;

- Analysis of organizational and technological documentation;

- Analysis of estimated calculations (cost expertise);

- Geodetic surveys;

- Carrying out verification constructive calculations.

The final part of the expert's conclusion is the conclusions, where the answers to the questions put to them are briefly given. The findings summarize the results of the study, which are presented in the previous section [3].

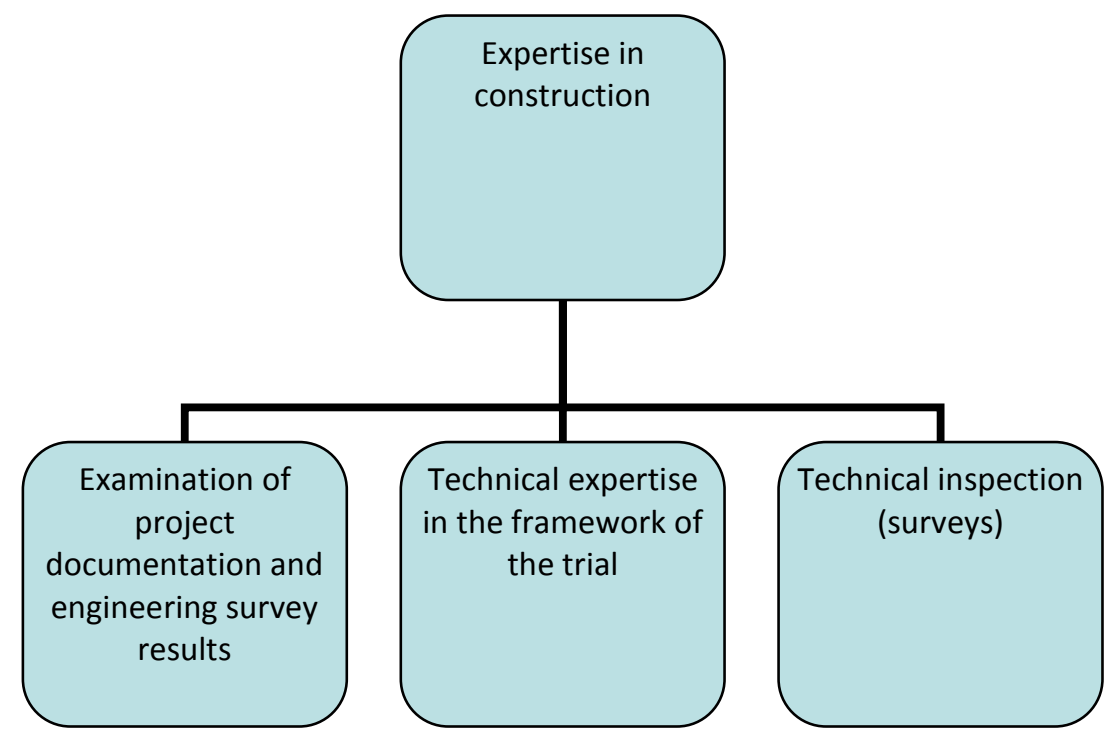

Fig. 1. Types of expertise

\section{Results and Discussion}

According to the Federal Law "On State Forensic Expertise in the Russian Federation", a citizen of the Russian Federation who has a higher education and additional professional education in a special expert specialty may hold an expert position in state forensic expert institutions [2].

The determination of the level of qualification of experts eligible for independent production in the field of forensic examination is established by expert-qualifying 
commissions in the manner prescribed by regulatory acts of federal bodies. These commissions monitor the level of expertise of experts every 5 years [5].

Table 1. Requirements for the qualifications of experts and tolerances for the study.

\begin{tabular}{|c|c|c|}
\hline No. & According to the Federal Law: & $\begin{array}{c}\text { According to the data obtained } \\
\text { experimentally: }\end{array}$ \\
\hline 1 & Higher education & Higher education \\
\hline 2 & $\begin{array}{c}\text { Additional professional education in } \\
\text { expert specialty }\end{array}$ & $\begin{array}{c}\text { Additional professional education in } \\
\text { expert specialty }\end{array}$ \\
\hline 3 & - & SRO tolerance \\
\hline 4 & - & $\begin{array}{c}\text { Membership in the national registry } \\
\text { of specialists }\end{array}$ \\
\hline 5 & - & Accreditation certificates \\
\hline
\end{tabular}

It is necessary to determine the main characteristics of the objects under study (see Table 2).

Table 2. The key card of the object under study.

\begin{tabular}{|c|c|c|}
\hline No & Characteristics of the object - representative & Characteristic value \\
\hline 1 & The functional purpose of the object & $\begin{array}{l}\text { Public building (multifunctional } \\
\text { shopping centers) }\end{array}$ \\
\hline 2 & Location & Moscow and the region \\
\hline 3 & Total area $\left(\mathrm{m}^{2}\right)$ & $80,000(+/-10,000)$ \\
\hline 4 & Constructive scheme & Monolithic reinforced concrete frame \\
\hline 5 & Object of examination & $\begin{array}{l}100 \% \text { of structures (bearing, } \\
\text { enclosing, self-supporting), } 100 \% \text { of } \\
\text { internal engineering systems }\end{array}$ \\
\hline \multirow[t]{4}{*}{6} & \multirow[t]{4}{*}{ Questions put for examination (expertise) } & $\begin{array}{l}\text { 6.1. Determining the amount of work } \\
\text { actually performed }\end{array}$ \\
\hline & & $\begin{array}{l}\text { 6.2. Determining the quality of the } \\
\text { work actually performed }\end{array}$ \\
\hline & & $\begin{array}{l}\text { 6.3. Determining the cost of the work } \\
\text { actually performed }\end{array}$ \\
\hline & & $\begin{array}{l}\text { 6.4. Determination of the suitability } \\
\text { of the object with actually detected } \\
\text { defects for further safe operation }\end{array}$ \\
\hline
\end{tabular}


These calculations on the composition of the executors of the study were conducted in an enlarged manner according to the principle of minimum sufficiency (see Table 3).

Table 3. The composition of the link performers to conduct an expert study of the construction object

\begin{tabular}{|l|l|l|}
\hline No & $\begin{array}{l}\text { Type of research as part of the examination of } \\
\text { the construction object }\end{array}$ & $\begin{array}{l}\text { The composition of the } \\
\text { link, people }\end{array}$ \\
\hline 1. & Visual inspection & 4 \\
\hline 2. & Laboratory research & 2 \\
\hline 3. & Documentary study & 3 \\
\hline 4. & Estimated calculation & 1 \\
\hline 5. & Calibration Design Calculations & 1 \\
\hline 6. & Research Coordination, Leading Expert & 1 \\
\hline
\end{tabular}

The subject of the study is to determine the suitability of the object with actually identified defects for further safe operation.

The object of study is the finished construction products in the composition of supporting, enclosing, self-supporting structures, a complex of internal engineering systems.

\section{Conclusions}

The regulated requirements for the tolerances and qualifications of the specialists and experts involved in the study, in terms of the expertise and audit of construction, reconstruction and conversion facilities, are not sufficiently determined. Empirical data, based on the reduced labor intensity, allowed to form the optimal minimum sufficient link of executors per room of the volume of the object of examination. This cast will allow you to better predict the timing, plan and organize work on the behavior of expert research, formulate the correct and most adequate conclusions taking into account the entire spectrum of research, including laboratory tests, visual instrumental, geodetic surveys, analysis of project, work and performance documentation, technological documentation, analysis of estimated calculations, geodetic surveys and carrying out verification design calculations.

\section{References}

1. P.G. Grabovy, O.I. YegorycheV, I.G. Lukmanov. Examination and inspection of the investment process and the operation of real estate, Part I. (Moscow: Prospect, 2012)

2. P.G. Grabovy, O.I. Yegorychev, I.G. Lukmanov. Examination and inspection of the investment process and the operation of real estate, Part II (Moscow: Prospect, 2012)

3. B.S. Istomin, N.A. Gariaev, A.G. Olohova. Design engineering in construction (MGSU, 2009)

4. Dmitry Topchiy, Ekaterina Kochurina Environmental situation in construction, reconstruction and re-profiling of facilities in high-density urban development (MATEC Web of Conferences 193, 05012, 2018)

5. Dmitriy Topchiy, Andrey Tokarskiy Formation of the organizational-managerial model of renovation of urban territories (MATEC Web of Conferences 196(1):04029, 2018)

6. D.V. Topchiy, A.I. Shatrova, Formation of a basic management strategy for a construction organization in the implementation of projects of redevelopment of major urban areas (International Journal of Mechanical Engineering and Technology, 2018) 
7. D. Topchiy, A. Tokarskiy, Designing of structural and functional organizational systems, formed during the re-profiling of industrial facilities (IOP Conference Series: Materials Science and Engineering, 2018)

8. Dmitriy Topchiy, Anastasia Shatrova, Alexey Yurgaytis, Integrated construction supervision as a tool to reduce the developer's risks when implementing new and redevelopment projects (MATEC Web of Conferences 193, 2018)

9. I.L. Abramov, A.A. Lapidus Formation of production structural units within a construction company using the systemic integrated method when implementing highrise development projects (E3S Web of Conferences 33, 2018)

10. Ivan Abramov, Formation of integrated structural units using the systematic and integrated method when implementing high-rise construction projects (HRC 2017 (HIGH-RISE CONSTRUCTION-2017) E3S Web of Conferences 33. D. Safarik, Y. Tabunschikov and V. Murgul (Eds.). 2018).

11. Azariy Lapidus, Ivan Abramov, Systemic integrated method for assessing factors affecting construction timelines (MATEC Web of Conferences 193, 2018)

12. A.Y. Batyrin, Yu.K. Orlov Construction and technical expertise in modern legal proceedings (Expert Library, 2010)

13. A.Y. Batyrin Collection of educational and methodical works on judicial construction and technical expertise (Expert Library, 2011)

14. P. Oleinik, A. Yurgaytis, Optimization of the annual construction program solutions (MATEC Web of Conferences, 117, 2017)

15. W. Bozejko, Z. Hejducki, M. Uchroński, M. Wodecki, Solving resource-constrained construction scheduling problems with overlaps by metaheuristic (Journal of Civil Engineering and Management, 2014) 